\title{
Analisis Efisiensi Teknis Usahatani Padi Di Kabupaten/Kota Jawa Timur Tahun 2020
}

\author{
Soleh Hanafi Ihsan, Mohtar Rasyid, Dyah Wahyuningsih \\ Universitas Trunojoyo Madura \\ Email: solehhanafi2184@gmail.com.
}

\begin{tabular}{l}
\hline \hline Article Info \\
\hline Article history: \\
Published: Dec 28, 2021 \\
Page: 1-10 \\
\hline
\end{tabular}

Keyword: usahatani padi, efisiensi teknis, DEA.

\begin{abstract}
Tujuan dari penelitian ini yaitu untuk mengetahui tingkat efisiensi teknis usatani padi di kabupaten/kota Jawa Timur tahun 2020. Hasil menunjukkan bahwa usahatani padi yang telah efisien dalam penggunaan input terdapat 27 Kabupaten/Kota atau sekitar 71,05 persen dari total, Sedangkan pada penelitian ini usahatani padi yang tidak efisien sejumlah 11 Kabupaten/Kota atau sekitar 28,94 persen. Hasil analissi menujukkan bahwa usahatani padi pada kabupaten/kota di Jawa Timur berada pada posisi meningkatkan skala pengembaliannya (increasing return to scale) yaitu berada di posisi dimana peningkatan output lebih besar daripada peningkatan input.
\end{abstract}

Kata Kunci : usahatani padi, efisiensi teknis, DEA

The purpose of this study is to determine the level of technical efficiency of rice farming in East Java districts/cities in 20192020. The results show that there are 27 regencies/cities or around 71.05 percent of the total, while in this study there are 11 regencies/cities or about 28.94 percent of the inefficient rice farms that have been efficient in using inputs. The results of the analysis show that rice farming in districts/cities in East Java is in a position to increase its return to scale, which is in a position where the increase in output is greater than the increase in inputs..

Keywords : rice farming, technical efficiency, DEA.

\section{Pendahuluan}

Sektor pertanian berperan penting dalam pembangunan dan perekonomian nasional. Sebagian besar penduduk Indonesia bermata pencaharian sebagai petani. Peranan sektor pertanian sangatlah penting yaitu sebagai penyedia bahan pangan, penyedia bahan baku bagi industriindustri, penyedia kesempatan berusaha, serta merupakan sumber pendapatan bagi

\section{Editorial Office:}

Prodi Ilmu Ekonomi Fakultas Ekonomi dan Bisnis Islam, UIN Sunan Ampel Surabaya

Jl. Ahmad Yani 117 Surabaya, Jawa Timur 60237, Indonesia.

Email: oje@uinsby.ac.id 
para petani. Salah satu komoditas pertanian yang sangat dibutuhkan masyarakat adalah padi. Padi merupakan komoditi penghasil beras yang menjadi tanaman pangan utama bagi penduduk Indonesia. Beberapa alasan penting perlu ditingkatkan produksi padi secara keberlanjutan yaitu beras merupakan bahan pangan pokok bagi masyarakat Indonesia, merupakan komoditas penting umtuk menjaga ketahanan pangan, usaha tani padi sudah merupakan bagian hidup dari petani Indonesia sehingga menciptakan lapangan kerja yang besar dan kontribusi dari usaha tani padi terhadap pendapatan rumah tangga cukup besar (Onibala et al. 2017).

Indonesia merupakan negara penghasilan beras terbesar nomor tiga di dunia. Hal ini dikarenakan luasnya area yang digunakan untuk produksi padi. Jika dilihat dari luas area penanaman padi, Indonesia memiliki lokasi penanaman padi yang sangat luas, yaitu sekitar 13,2 juta hektar pada tahun 2010. Angka ini naik pada tahun 2015 menjadi 15,79 juta hektar. Kemudian pada 2017, luas lahan padi di Indonesia kembali mengalami peningkatan, yakni menjadi 15,81 juta hektar. Dari 261,1 juta penduduk di Indonesia, terdapat sekitar 25,9 juta petani yang menanam padi. Angka tersebut merupakan $77 \%$ dari keseluruhan jumlah petani yang ada di Indonesia. Lahan padi banyak ditemukan di daerah-daerah Indonesia bagian barat, terutama Pulau Jawa. Hampir 60\% total produksi padi berasal dari pulau Jawa yang juga memiliki penduduk terbanyak di Indonesia. Di antara semua provinsi, Jawa Timur adalah wilayah yang memiliki lahan padi terbesar, yaitu 2,29 juta hektar atau sekitar $15 \%$ dari keseluruhan luas lahan padi di Indonesia (Badan Pusat Statistika, 2020).

Provinsi Jawa Timur memberikan sumbangan besar bagi pemenuhan kebutuhan pangan nasional. Data menyebutkan, tahun 2020, Jawa Timur memberikan sumbangan produksi padi sebesar $18,2 \%$ terhadap kebutuhan nasional.
Hampir 5 juta atau 19 persen dari sekitar 25,5 juta rumah tangga pertanian di Indonesia berada di Provinsi Jawa Timur di mana jumlah ini adalah yang terbanyak dibandingkan dengan provinsi-provinsi lainnya di Indonesia (Badan Pusat Statistika, 2020).

Tabel 1.1

6 Provinsi Penghasil Padi di Pulau Jawa Tahun 2020

\begin{tabular}{|c|l|c|c|c|}
\hline No & \multicolumn{1}{|c|}{ Provinsi } & $\begin{array}{c}\text { Luas Lahan } \\
(\mathrm{Ha})\end{array}$ & $\begin{array}{c}\text { Produktivitas } \\
(\mathrm{Ku} / \mathrm{Ha})\end{array}$ & $\begin{array}{c}\text { Produksi } \\
(\mathrm{Ton})\end{array}$ \\
\hline 1 & Jawa Timur & $1.754 .380,30$ & 56.68 & 9.944 .538 .26 \\
\hline 2 & Jawa Tengah & 1.666 .931 .49 & 56.93 & 9.489 .164 .62 \\
\hline 3 & Jawa Barat & 1.586 .888 .63 & 56.82 & 9.016 .772 .58 \\
\hline 4 & Banten & 325.333 .24 & 50.88 & 1.655 .170 .09 \\
\hline 5 & Di Yogyakarta & 110.548 .12 & 47.35 & 523.395 .95 \\
\hline 6 & Dki Jakarta & 914.51 & 49.69 & 4543.93 \\
\hline
\end{tabular}

Sumber : Statistik Indonesia 2020

Tabel 1.1 menunjukkan Luas Panen, Produksi, Produktivitas produksi padi di enam provinsi yang berada di pulau jawa. Diperingkat pertama di tempati Provinsi Jawa Timur dengan Luas lahan sebesar 1.754.380,30 hektar, produksi padi sebesar 9.944.538,26 ton, dan memiliki tingkat produktivitas sebesar 56.68. Diperingkat kedua di tempati Provinsi Jawa Tengah dengan luas lahan sebesar 1.666.931.49 hektar, produksi padi sebesar 9.489.164.62 ton, dan tingkat produktivitasnya sebesar 56.93. Kemudian diperingkat ketiga ditempati Provinsi Jawa Barat dengan luas lahan 1.586.888.63 hektar, produksi padi sebesar 9.016.772.58 ton, dan tingkat produktivitasnya sebesar 50.88. Kemudian di peringkat empat, lima dan enam di tempati provinsi Banten, DI Yogyakarta, dan DKI Jakarta yang mempunyai luas lahan kurang dari lima ratus ribu hektar dan produksi padi kurang dari lima juta ton padi.

Upaya untuk meningkatkan produksi pertanian (padi) telah banyak dilakukan baik oleh pemerintah melalui lembaga-lembaga penelitian, lembaga swadaya masyarakat, dan perguruan tinggi. Akan tetapi didalam 
pelaksanaannya diperoleh fakta bahwa masih terjadi perbedaan yang tinggi antara potensial produksi padi berbeda dengan hasil yang diperoleh petani. Perbedaan hasil umumnya disebabkan oleh faktor sosial ekonomi dan faktor teknis. Faktor sosial ekonomi yaitu kondisi keterbatasan petani untuk menggunakan inovasi teknologi budidaya, seperti pengetahuan, akses terhadap sumber modal, pemasaran, prasarana transportasi, irigasi. Sedangkan faktor teknis ketersediaan air irigasi, kondisi kesuburan lahan, hama dan penyakit tanaman. Faktor-faktor ini akan menjadi pertimbangan bagi petani dalam mengalokasikan input seperti bibit, pupuk, tenaga kerja, dan obat-obatan.

Hasil penelitian yang dilakukan Khai and Yabe (2011); Onibala et al. (2017) menyebutkan variabel yang pengaruh secara signiifikan terhadap produksi padi adalah luas lahan, jumlah benih, pupuk, tenaga kerja terhadap produksi padi sawah. Arnanda et al, 2016), luas lahan, jumlah penggunaan pupuk urea, jumlah penggunaan pupuk $\mathrm{KCl}$, jumlah penggunaan pupuk SP36 ,jumlah penggunaan pupuk NPK, jumlah penggunaan pupuk organik cair, Jumlah penggunaan pestisida, jumlah benih yang digunakan dalam satu kali proses produksi, jumlah penggunaan tenaga kerja, jumlah penggunaan jam kerja mesin, jenis bibit, umur petani, pengalaman berusahatani, dan pendidikan petani. Sedangkan Basorun \& Fasakin (2012), menyebutkan status pernikahan petani padi, luas lahan ditanami, ketersediaan pasar padi, jumlah buruh yang terlibat dalam produksi dan penggunaan agro-kimia.

Penggunaan faktor produksi yang tidak efisien dalam usahatani padi sawah akan mengakibatkan rendahnya produksi dan tingginya biaya, dan pada akhirnya mengurangi pendapatan petani. Bagi petani kegiatan usahatani yang dilakukan tidak hanya meningkatkan produksi tetapi bagaimana menaikkan pendapatan melalui pemanfaatan penggunaan faktor produksi.
Pengelolaan input produksi harus mempertimbangkan prinsip optimalisasi guna pencapaian produksi yang tinggi dengan alokasi input yang efisien dan efektif. Menurut Soekartawi (2006), efisien ini dapat digolongkan menjadi tiga macam, yaitu efisiensi teknis, efisiensi alokatif (efisiensi harga), dan efisiensi ekonomi. Petani sebagai entrepreneur akan bertindak secara rasional dan logis dalam pengelolaan usahataninya. Sumberdaya yang terbatas akan dimanfaatkan oleh petani secara efisien guna memperoleh keuntungan yang maksimum. Akan tetapi karena keterbatasan ekonomi, pengetahuan usahatani maka tingkat penggunaan sumberdaya secara optimal belum tercapai.

Berdasarkan uraian di atas, upaya peningkatan produktivitas melalui efisiensi produksi menjadi penting untuk diperhatikan. Penelitian ini akan menganalisis peluang untuk meningkatkan produksi padi di Kabupaten/Kota Jawa Tmur melalui efisiensi produksi usahatani. Berdasarkan latar belakang tersebut, maka selanjutnya akan dilakukan penelitian yang berjudul "Analisis Efisiensi Teknis Produksi Usahatani Padi Di Kabupaten/Kota Jawa Timur Tahun 2020”.

\section{Kajian Pustaka \\ Efisiensi}

Efisiensi merupakan perbandingan output dengan input yang digunakan dalam suatu proses produksi. Secara umum konsep efisiensi didekati dari dua sisi pendekatan yaitu dari sisi alokasi penggunaan input dan dari sisi output yang dihasilkan. Pendekatan dari sisi input yang dikemukakan Farrell dalam Marjelita (2015), membutuhkan ketersediaan informasi harga input dan sebuah kurva isoquant yang menunjukkan kombinasi input yang digunakan untuk menghasilkan output secara maksimal. Pendekatan dari sisi output merupakan pendekatan yang digunakan untuk melihat sejauh mana jumlah output secara proporsional dapat ditingkatkan tanpa 
mengubah jumlah input yang digunakan. Coelli dkk (1998), menyatakan bahwa konsep efisiensi dibedakan menjadi tiga, yaitu: 1) efisiensi teknis, 2) efisiensi harga, dan 3) efisiensi ekonomis. Efisiensi teknis adalah perbandingan antara produksi actual dengan tingkat produksi yang potensial dapat dicapai (Soekartawi, 2006).

Efisiensi harga atau alokatif menunjukkan hubungan biaya dan output. Efisiensi alokatif tercapai jika perusahaan tersebut mampu memaksimalkan keuntungan yaitu menyamakan nilai produk marjinal setiap faktor produksi dengan harganya. Bila petani mendapatkan keuntungan yang besar dari usahataninya, misalnya karena pengaruh harga, maka petani tersebut dapat dikatakan mengalokasikan input usahataninya secara efisien. Efisiensi ekonomis adalah adalah kombinasi antara efisiensi teknis dan efisiensi alokatif. Untuk mengukur efisiensi produksi dalam teori produksi menggunakan dua pendekatan yaitu pendekatan stokastik dan deterministik. Pendekatan stokastik contohnya adalah fungsi-fungsi yang menggunakan ekonometrik seperti fungsi produksi Cobb-Douglas. Pendekatan deterministik adalah konsep pengukuran efisiensi atau optimalitas dengan menggunakan Linear Programming, dalam hal ini yang menggunakan Linear Programming adalah Data Envelopment Analisis (DEA).

Menurut Coelli dkk (1998), pada model DEA diasumsikan entitas yang dievaluasi menggunakan set input yang sama untuk menghasilkan set output yang sama pula. Data bernilai positif dan bobot dibatasi pada nilai positif. Input dan output bersifat variabel. Keunggulan metode DEA adalah biasa menangani banyak input dan output. Tidak butuh asumsi hubungan fungsional antara variabel input dan output. DMU dibandingkan secara langsung dengan sesamanya. Input dan output dapat memiliki satuan pengukuran yang berbeda.
Kelemahan DEA adalah bersifat simpel spesifik.

\section{Produksi}

Secara sederhana produksi dapat dikatakan sebagai kegiatan yang ditujukan untuk menghasilkan dan menambah nilai suatu barang. Pengertian produksi yang pernah dikemukakan oleh para ahli ekonomi baik klasik maupun modern hanya berbeda pada penyajiannya tetapi dalam arti sesungguhnya dan produksi itu sendiri pada prinsipnya adalah sama. Pengertian produksi yang dikemukakan oleh International Labor Organization adalah suatu hasil dari input komponen utama yaitu tanah, kapital, buruh dan organisasi (Lopang, 2016). Dari pengertian tentang produksi diatas, maka dapat diartikan bahwa produksi adalah hasil akhir dari proses atau aktivitas ekonomi dengan memanfaatkan beberapa masukan atau input. Sehingga dalam penelitian penulis yang meneliti tentang produksi di bidang pertanian, maka penulis menyimpulkan bahwa produksi pertanian. Faktor produksi adalah segala sesuatu yang dibutuhkan dalam proses produksi barang dan jasa. Faktor-faktor Produksi:

1. Faktor sumber daya alam/fisik Adalah faktor produksi yang bersumber dari kekayaan alam. Sumber daya alam dapat memenuhi kebutuhan manusia untuk hidup

2. Faktor Sumber Daya Manusia/Tenaga Kerja Adalah faktor produksi yang melakukan kegiatan produksi, baik secara langsung maupun tidak langsung. Faktor tenaga kerja dapat di bagi tiga menjadi dua, yaitu: Tenaga kerja terdidik, yaitu yang pertama tenaga kerja yang memerlukan pendidikan formal untuk dapat melaksanakan pekerjaannya. Minsalnya dokter, arsitek, dosen,ddl. Dan yang kedua tenaga kerja terampil tenaga kerja yang memerlukan keterampilan khusus agar bisa melaksanakan 
pekerjaannya. Minsalnya penjahit, tukang, supir, kapster salon,dll. Kemudian yang ketiga Tenaga tidak terdidik dan tidak terlatih, yaitun tenaga kerja yang tidak membutuhkan pendidikan atau pelatihan tertentu agar bisa melaukan pekerjaannya. Minsalnya asisten rumah tangga, kuli bangunan, petugas kebersihan,dll.

3. Faktor modal Punya peranan penting dalam percepatan dan kelancarn kegiatan produksinya. Modal dapat dibagi menjadi beberapam kelompok, yaitu: bedasarkan sumbernya, bedasarkan sifatnya, bedasarkan bentuknya dan bedasarkan kepemilikannya

4. Faktor kewirausahaan yang dimiliki oleh seseorang wirausaha adalah perencanaan (Planning), pengorganisasian (Organizing), penggerakkan (Actuating) dan pengawasan (Controling)

5. Faktor sumber daya informasi Keseluruhan informasi dan data yang diperlukan oleh perusahaan untuk mengoperasi bisnisnya. Adapun beberapa informasi dan data tersebut adalah prediksi kondisi pasar di masa depan, data dan informasi ekonomi dan pengetahuan karyawan.

\section{Metode Penelitian}

Penelitian ini menggunakan penedekatan kuantitatif dengan analisis Data Envelopment Analysis (DEA). Metode ini digunakan untuk meganalisis efisiensi teknis usahatani padi di kabupaten/kota jawa timur tahun 2020. Penelitian ini dilakukan pada 38 Kabupaten/Kota provinsi Jawa Timur pada tahun 2020. Data sekunder yang telah terkumpul diolah menggunakan DEA. Model yang digunakan dalam analisis data ini yaitu berorientasi pada input, menggunakan pendekatan VRS (Variable Return to Scale).

\section{Operasionalisasi Variabel}

Dalam penelitian ini, variabel yang digunakan mencakup sebagai berikut:

\section{Tabel 1 Operasionalisasi Variabel}

\begin{tabular}{|l|c|}
\hline \multicolumn{1}{|c|}{ Variabel dan definisi } & \multirow{2}{|c|}{ Indikator } \\
\hline $\begin{array}{l}\text { komponen produksi } \\
\text { dari suatu usaha yang } \\
\text { digunakan } \\
\text { dalam proses } \\
\text { menghasilkan output }\end{array}$ & $\begin{array}{l}\text { tenaga kerja, luas panen, } \\
\text { pupuk urea, pupuk SP- } \\
\text { Variabel output }\end{array}$ \\
\hline $\begin{array}{l}\text { komponen hasil produksi } \\
\text { yang dihasilkan dari } \\
\text { mengolah input }\end{array}$ & produksi/ton \\
\hline
\end{tabular}

\section{Teknik Analisis}

Data Envelopment Analysis (DEA) yang mengukur tingkat efisiensi suatu DMU (Decision Making Unit) dan membandingkannya dengan DMU yang lainnya. DEA adalah Teknik analisis yang mengakomodasi banyak input dan output dengan perhitungan model linier untuk mendapatkan nilai efisiensi untuk setiap pengamatan (Bogetoft \& Otto, 2011). Orientasi input digunakan apabila penekanan pada pengurangan input untuk meningkatkan efisiensi. Orientasi input mengasumsikan bahwa manajemen memiliki kontrol yang lebih terhadap input daripada output, dengan kata lain manajemen mampu menambah dan mengurangi input dengan mudah. Orientasi output digunakan apabila penekanan pada peningkatan output dengan input yang tersedia untuk meningkatkan nilai efisiensi. Nilai ini bisa digunakan utuk mengukur efisiensi teknis, skala efisiensi, dan efisiensi alokatif (Silfia et al. 2021). Model matematis yang umum digunakan dalam DEA adalah sebagai berikut (Cooper et al., 2002) :

\section{Model Constan Return to Scale (CRS)}

Model CRS Model CRS dapat diartikan jika terdapat penambahan input sebesar $\mathrm{x}$ kali, maka output juga akan bertambah sebesar x kali. asumsi lain yang digunakan adalah setiap perusahaan atau 
Decision making Unit (DMU) beroperasi pada skala optimal. Rumusnya adalah sebagai berikut :

Max $\Theta$ (Efisiensi DMU Model Max $\Theta$ (Efisiensi DMU Model CRS)

$\sum=1 x i j^{\prime} i j \geq \theta i 0 n j$

$\mathrm{i}=1,2, \ldots, \mathrm{m}$

$\sum=1 y r j{ }^{\prime} j n j \geq y i 0$

$\mathrm{r}=1,2, \ldots, \mathrm{s}$

$\sum=1 j^{\prime} \geq 0 n j$

$\mathrm{j}=1,2, \ldots, \mathrm{n}$

Di mana:

$\Theta=$ efisiensi teknis (CRS) $\mathrm{n}=$ jumlah DMU

$\mathrm{m}=$ jumlah input $\mathrm{s}=$ jumlah output

$x i j=$ jumlah input tipe ke-i dari DMU ke-j

yrj = jumlah output tipe ke-r dari DMU ke-j

\section{Model Variabel Return To Scale (VRS)}

Model VRS dapat diartikan sebagai tambahan input sebesar $\mathrm{x}$ kali tidak akan menyebabkan output meningkat seebsar $\mathrm{x}$ kali, bisa lebih kecil atau lebih besar dari $\mathrm{x}$ kali. peningkatan yang terjadi bisa bersifat Increasing Return To Scale (IRS) atau bisa juga bersifat Decreasing Return To Scale (DRS). Secara matematis dapat dirumuskan sebagai berikut:

$\sum x j=1 n j=1$

Selanjutnya model BCC dapat ditulis dengan persamaan berikut:

Max (Efisiensi DMU Model VRS)

$\sum=1 x i j^{\prime} i j \geq x i 0 n j$

$\mathrm{i}=1,2, \ldots, \mathrm{m}$

$\sum=1 y r j{ }^{\prime} j \geq y i 0 n j$

$\mathrm{r}=1,2, \ldots, \mathrm{j}$

$\sum=1 j^{\prime} \geq 1 n j$

(VRS)

$\sum=1^{\prime} j \geq 0 n j$

$\mathrm{j}=1,2, \ldots, \mathrm{n}$

$\Theta=$ efisiensi teknis (VRS) $n=$ jumlah DMU

$\mathrm{m}=$ jumlah input $\mathrm{s}=$ jumlah output

$x i j=$ jumlah input ke-i dari DMU ke-j yrj = jumlah output ke-r dari DMU ke-j

$\mathrm{j} j=$ bobot DMU $\mathrm{j}$ untuk DMU yang dihitung

DMU yang tidak efisien menunjukkan

adanya kinerja yang kurang baik dari sisi input, output, atau dari sisi keduanya apabila input yang dipakai tidak efisien maka dinamakan input slack, sedangkan apabila output yang dihasilkan masih belum efisien maka dinamakan output slack. Input slack merupakan pengurangan secara proposional input yang digunakan agar unit tersebut mencapai titik efisien dan dimana DMU paling efisien berada. Menurut MousaviAvval et al. (2011) dalam DEA, DMU yang tidak efisien dapat dibuat menjadi efisien, baik dengan meminimalkan tingkat input dengan mempertahankan tingkat output yang sama (input oriented), atau dengan meningkatkan output dengan membuat input tetap (output oriented).

Hasil perhitungan selalu menunjukkan kurang dari atau sama dengan satu. DMU yang nilainya kurang dari 1 maka dikatakan kurang efisien sedangkan DMU yang sama dengan 1 memliki arti efisien.

\section{Hasil dan Pembahasan \\ Pertanian Padi di Jawa Timur}

Jawa Timur merupakan provinsi penyangga pangan nasional, sehingga perkembangan padi, jagung, dan kedelai merupakan komoditas utama yang sangat berperan untuk dapat mewujudkan ketahan pangan dengan perkembangan produksi tanaman pangan dan hortikultura. Komoditas tanaman pangan yang dihasilkan di Jawa Timur adalah padi, jagung, kacang tanah, ubi jalar, ubi kayu, kedelai dan kacang hijau. Produksi tanaman pangan terbesar tahun 2020 adalah tanaman padi, dengan jumlah produksi dalam bentuk Gabah Kering Giling (GKG) lebih dari 9,94 juta 
ton. Luas panen tanaman padi Provinsi Jawa Timur tahun 2020 hasil pengamatan KSA sebesar 1.754.380 hektar. Luas panen tersebut mengalami peningkatan dibandingkan tahun 2019 yang mencapai 1.702.426 hektar. Distribusi luas panen padi menurut kabupaten/kota di Provinsi Jawa Timur tahun 2020 sebagai berikut Kabupaten Lamongan menjadi kabupaten dengan luas panen terbesar (148.031 hektar), diikuti Kabupaten Bojonegoro seluas 135.635 hektar, dan Kabupaten Ngawi 125.908 hektar. Sedangkan untuk kabupaten/kota dengan luas panen terkecil diisi oleh Kota Mojokerto (733,26 hektar), Kota Batu (750,11 hektar), Kota Blitar (771,27 hektar).

Pertumbuhan luas panen pada 3 kabupaten/kota dengan luas panen terbesar antara lain Kabupaten Lamongan tumbuh sebesar 5,39 persen, selaunjutnya di Kabupaten Bojonegoro tumbuh sebesar 5,25 persen, dan Kabupaten Ngawi tumbuh sebesar 2,78 persen dibandingkan luas panen di tahun 2019. Upaya perbaikan yang dilakukan oleh pemerintah diharapkan mampu mencukupi kebutuhan akan tanaman pangan dari hasil dalam negeri sendiri dan mengurangi ketergantungan terhadap impor hasil pertanian luar negeri (Badan Pusat Statistika, 2020). Dalam kurun waktu lima tahun terakhir, produktivitas padi mengalami fluktuasi yang tidak menentu, produktivitas tertinggi tercatat pada tahun 2016 sebesar 5,98 ton per hektar dan produktivitas terendah tercatat pada tahun 2019 sebesar 5,63 ton per hektar, pada tahun 2020 5,67 ton per hektar. Menurut Dinas Pertanian Provinsi Jawa Timur (2014) selama ini pertumbuhan produksi pertanian di Jawa Timur masih berbasis pada ketersedian lahan, pertumbuhan produktivitas masih mengalami peningkatan yang cenderung melambat, sehingga kontribusi pertanian Jawa Timur terhadap perekonomian nasional semakin menurun.

\section{Efisiensi Teknis Usahatani Padi}

Analisis efisiensi teknis dilakukan melalui pendekatan Data Envelopment Analysis (DEA) dengan orientasi input dan variable return to scale. Data yang digunakan dalam penelitian ini adalah data pada musim tanam 2020. Variabel output yang digunakan yaitu produksi padi/ton, Sedangkan variabel input yang digunakan tenaga kerja, luas panen, pupuk urea, pupuk SP-36.

Berdasarkan hasil perhitungan menggunakan DEAP versi 2.1, diperoleh hasil yang menunjukkan bahwa usatani padi di kabupaten/kota Jawa Timur yang memiliki nilai efisiensi sama dengan satu sebesar 21,05 persen, sedangkan persentase usahatani padi yang memiliki nilai efisiensi kurang dari satu sebesar 78,95 persen dari total (untuk model DEA VRS). Dari hasil analisis data pengolahan data input dan output dengan bantuan software DEA maka diperoleh tingkat efisiensi usahatani padi di kabupaten/kota Jawa Timur sebagai berikut:

Tabel 1. Tingkat Efisiensi Teknis Usahatani padi di Kabupaten/Kota Jawa Timur Tahun 2020

\begin{tabular}{|c|c|c|}
\hline NO & DMU & Efisiensi Teknis \\
\hline 1 & Pacitan & 0.838 \\
\hline 2 & Ponorogo & 1.000 \\
\hline 3 & Trenggalek & 1.000 \\
\hline 4 & Tulungagung & 1.000 \\
\hline 5 & Blitar & 1.000 \\
\hline 6 & Kediri & 1.000 \\
\hline 7 & Malang & 1.000 \\
\hline 8 & Lumajang & 0.881 \\
\hline 9 & Jember & 1.000 \\
\hline 10 & Banyuwangi & 0.948 \\
\hline 11 & Bondowoso & 0.829 \\
\hline 12 & Situbondo & 1.000 \\
\hline 13 & Probolinggo & 1.000 \\
\hline 14 & Pasuruan & 0.849 \\
\hline 15 & Sidoarjo & 1.000 \\
\hline 16 & Mojokerto & 1.000 \\
\hline
\end{tabular}




\begin{tabular}{|l|c|l|}
17 & Jombang & 0.953 \\
\hline 18 & Nganjuk & 1.000 \\
\hline 19 & Madiun & 0.946 \\
\hline 20 & Magetan & 1.000 \\
\hline 21 & Ngawi & 1.000 \\
\hline 22 & Bojonegoro & 0.918 \\
\hline 23 & Tuban & 1.000 \\
\hline 24 & Lamongan & 1.000 \\
\hline 25 & Gresik & 0.953 \\
\hline 26 & Bangkalan & 0.823 \\
\hline 27 & Sampang & 1.000 \\
\hline 28 & Pamekasan & 1.000 \\
\hline 29 & Sumenep & 1.000 \\
\hline 30 & Kota Kediri & 1.000 \\
\hline 31 & Kota Blitar & 1.000 \\
\hline 32 & Kota Malang & 1.000 \\
\hline 33 & Kota & 1.000 \\
\hline 34 & Probolinggo & \\
\hline 35 & Kota Pasuruan & 1.000 \\
\hline 36 & Kota Mojokerto & 1.000 \\
\hline 37 & Kota Madiun & 1.000 \\
\hline 38 & Kota Burabaya & 0.993 \\
\hline
\end{tabular}

al. (2014) terdapat sekitar $30 \%$ petani yang tidak efisien secara teknis.

Output lain yang diperoleh dari perhitungan dengan menggunakan Data Envelopment Analysis (DEA) yaitu diperolehnya keterangan yang menunjukkan kecenderungan tren pada usahatani padi di lokasi penelitian. Model DEA CRS dan VRS digunakan untuk menentukan kecenderungan tren pada usahatani padi di lokasi penelitian tergolong pada increasing return to scale (IRS), decreasing return to scale (DRS), atau constant return to scale (CRS). Hasil analissi menujukkan bahwa usahatani padi pada kabupaten/kota di Jawa Timur berada pada posisi meningkatkan skala pengembaliannya (increasing return to scale) yaitu berada di posisi dimana peningkatan output lebih besar daripada peningkatan input yang terlihat pada tabel 2 .

Tabel 2. Variable Return to Scale Technical Efficiency (VRSTE), dan Scale Efficiency (SE)

Sumber : Hasil olah DEAP v2.1

Pada tabel 1 menunjukkan bahwa terlihat bahwa usahatani padi yang telah efisien dalam penggunaan input terdapat 27 Kabupaten/Kota atau sekitar 71,05 persen dari total yaitu Ponorogo, Trenggalek, Tulungagung, Blitar, Kediri, Malang, Jember, Situbondo, Probolinggo, Sidoarjo, Mojokerto, Nganjuk, Magetan, Ngawi, Tuban, Lamongan, Sampang, Pamekasan, Sumenep, Kota Kediri, Kota Blitar, Kota Malang, Kota Probolinggo, Kota Pasuruan, Kota Mojokerto, Kota Madiun Kota Batu. Hasil ini menunjukkan bahwa sebagian besar usahatani padi di Kabupaten/Kota Jawa Timur telah efisien secara teknis. Sedangkan pada penelitian ini usahatani padi yang tidak efisien sejumlah 11 Kabupaten/Kota atau sekitar 28,94 persen yaitu Pacitan, Lumjang, Bondowoso, Pasuruan, Jombang, Madiun, Bojonegoro, Gresik, Bangkalan, dan Kota Surabaya. Hal ini tidak jauh berbeda dengan penelitian Ibrahim et

\begin{tabular}{|c|c|c|}
\hline DMU & VRSTE & scale \\
\hline Pacitan & 0.838 & 0.770 irs \\
\hline Ponorogo & 1.000 & 0.885 irs \\
\hline Trenggalek & 1.000 & 0.826 irs \\
\hline Tulungagung & 1.000 & 0.918 irs \\
\hline Blitar & 1.000 & 0.864 irs \\
\hline Kediri & 1.000 & 0.904 irs \\
\hline Malang & 1.000 & 0.884 irs \\
\hline Lumajang & 0.881 & 0.911 irs \\
\hline Jember & 1.000 & $1000-$ \\
\hline Banyuwangi & 0.948 & 0.935 irs \\
\hline Bondowoso & 0.829 & 0.884 irs \\
\hline Situbondo & 1.000 & 0.782 irs \\
\hline Probolinggo & 1.000 & 0.791 irs \\
\hline Pasuruan & 0.849 & 0.908 irs \\
\hline Sidoarjo & 1.000 & 1.00 irs \\
\hline Mojokerto & 1.000 & 0.873 irs \\
\hline Jombang & 0.953 & 0.980 irs \\
\hline Nganjuk & 1.000 & 0.942 irs \\
\hline Madiun & 0.946 & 0.983 irs \\
\hline Magetan & 1.000 & $1000-$ \\
\hline
\end{tabular}




\begin{tabular}{|c|c|c|} 
Ngawi & 1.000 & $1000-$ \\
\hline Bojonegoro & 0.918 & 0.942 irs \\
\hline Tuban & 1.000 & 0.857 irs \\
\hline Lamongan & 1.000 & $1000-$ \\
\hline Gresik & 0.953 & 0.981 irs \\
\hline Bangkalan & 0.823 & 0.897 irs \\
\hline Sampang & 1.000 & 0.760 irs \\
\hline Pamekasan & 1.000 & 0.756 irs \\
\hline Sumenep & 1.000 & 0.821 irs \\
\hline Kota Kediri & 1.000 & 0.853 irs \\
\hline Kota Blitar & 1.000 & $1000-$ \\
\hline Kota Malang & 1.000 & $1000-$ \\
\hline Kota Probolinggo & 1.000 & 0.771 irs \\
\hline Kota Pasuruan & 1.000 & 0.893 irs \\
\hline Kota Mojokerto & 1.000 & 0.960 irs \\
\hline Kota Madiun & 1.000 & $1000-$ \\
\hline Kota Surabaya & 0.993 & 0.854 irs \\
\hline Kota Batu & 1.000 & 0.989 irs \\
\hline Sumber $:$ Hasi
\end{tabular}

Sumber : Hasil olah DEAP v2.1

Secara umum, usahatani padi di kabupaten/kota Jawa Timur telah efisien secara teknis karena sebagian besar petani menggunakan input yang sesuai dan tidak berlebih. Hal ini bisa dilihat dari penggunaan input tenaga kerja yang berlebih hanya sejumlah 31,57 persen (12 kabupaten/kota), input luas lahan sejumlah 28,94 persen (11 kabupaten/kota), input pupuk urea sejumlah 4,38 persen (4 kabupaten/kota) dan pupuk SSP-36 sejumlah 23,68 persen (9 kabupaten/kota).

Berdasarkan beberapa penjelasan di atas, dapat disimpulkan bahwa secara umum, usahatani padi di kabupten/kota di Jawa Timur pada musim tanam 2019-2020 efisien secara teknis.

\section{Kesimpulan}

Berdasarkan hasil analisis di atas, maka dapat disimpulkan bahwa Hasil penelitian menunjukkan bahwa usahatani padi di kabupaten/kota di Jawa Timur telah efisien dalam penggunaan input-input produksi-nya pada musim tanam tahun 2020.

\section{SARAN}

Berdasarkan kesimpulan di atas, maka saran yang dapat disampaikan adalah untuk dapat melakukan usahatani padi yang efisien secara teknis, petani responden di lokasi penelitian dapat mengurangi penggunaan input produksi yang masih berlebih. input tenaga kerja merupakan input produksi yang memiliki persentase pengurangan terbesar apabila dibandingkan dengan input-input produksi lainnya. Oleh karena itu, petani dapat mengurangi penggunaan tenaga kerja agar usahatani padi yang dilakukan efisien secara teknis. Selain itu diharapkan adanya penelitian lebih lanjut mengenai efisiensi alokatif dan efisiensi ekonomis dari usahatani padi.

\section{Daftar Pustaka}

Arnanda, Raffy, Syaiful Hadi, and Roza Yulida. 2016. "Efisiensi Produksi Padi Di Kecamatan Kuala Kampar Kabupaten Pelalawan." Sorot 11(2):111.

Badan Pusat Statistika. 2020. "Statistik Luas Panen Dan Produksi Padi." Berita Resmi Statistik 2(16):1-12.

Basorun J.O. and Fasakin J.O. (2012): Factors influencing rice production in Igbemo-Ekiti Region of Nigeria. Journal of Agriculture, Food \& Environmental Science. 5:1-9

Khai, Huynh Viet, and Mitsuyasu Yabe. 2011. "Technical Efficiency Analysis of Rice Production." The International Society for Southeast Asian Agricultural Sciences 17(1):135-46.

Onibala, Alvio G., Mex L. Sondakh, Rine Kaunang, and Juliana Mandei. 2017. "Analisis Faktor-Faktor Yang Mempengaruhi Produksi Padi Sawah Di Kelurahan Koya, Kecamatan Tondano Selatan." Agri-Sosioekonomi 13(2A):237. 
Silfia, Betty, Ayu Utami, Maziyah Mazza

Basya, and Anung Yoga Anindhita. 2021. "Efisiensi Anggaran Belanja Bidang Pendidikan Kabupaten / Kota Di Jawa Timur Tahun 2018." Equilibrium: Jurnal EkonomiManajemen-Akuntansi 17(2):98-104.

Soekartawi. 2006. Teori Ekonomi Produksi dengan Pokok Bahasan Analisis Fungsi Cobb-Douglas. Jakarta: Rajawali Press

Srirande. (2012). Pertumbuhan provinsi agraris. Jakarta: Kencana. 